\title{
A Trend Analysis of Temperature and Rainfall to Predict Climate Change for Northwestern Region of Bangladesh
}

\author{
Md. Didarul Islam Bhuyan ${ }^{*}$, Md. Mohymenul Islam¹, Md. Ebrahim Khalil Bhuiyan² \\ ${ }^{1}$ Department of Physics, Mawlana Bhashani Science and Technology University, Santosh, Tangail, Bangladesh \\ ${ }^{2}$ Department of Textile Engineering, Bangladesh University of Business and Technology, Dhaka, Bangladesh \\ Email: *didar_bhuiyan@yahoo.com
}

How to cite this paper: Bhuyan, M.D.I., Islam, M.M. and Bhuiyan, M.E.K. (2018) A Trend Analysis of Temperature and Rainfall to Predict Climate Change for Northwestern Region of Bangladesh. American Journal of Climate Change, 7, 115-134. https://doi.org/10.4236/ajcc.2018.72009

Received: January 1, 2018

Accepted: April 15, 2018

Published: April 18, 2018

Copyright $\odot 2018$ by authors and Scientific Research Publishing Inc. This work is licensed under the Creative Commons Attribution International License (CC BY 4.0).

http://creativecommons.org/licenses/by/4.0/

\begin{abstract}
Bangladesh is one in all the foremost climate vulnerable countries of the world. In recent years, climate change studies over the country get plenty of attention by the researchers and policy makers. A substantial quantity of global climate change studies over the country use climate models to estimate future projections and uncertainties. Maximum temperature, precipitation and their potential future changes are evaluated in an ensemble of the 5th Phase Coupled Model Inter-comparison Project (CMIP5) within the Intergovernmental Panel on Climate Change (IPCC) diagnostic exercise for the Fifth Assessment Report (AR5) and the available historical data collected by the Bangladesh Meteorological Department (BMD) during the period 1981-2008 in the north-western region of Bangladesh and also the comparison between these two values. It has been found that average maximum temperature shows a positive trend of increase at a rate of $0.29^{\circ} \mathrm{C}$ and $5.3^{\circ} \mathrm{C}$ per century respectively, for BMD data and MPI-ESM-LR (CMIP5) model data. But the rainfall is decreasing at a rate of $8.8 \mathrm{~mm}$ and $40.1 \mathrm{~mm}$ per century respectively for BMD data and MPI-ESM-LR (CMIP5) model data. It is seen that July was the maximum monsoon rainfall month and January was the lowest rainfall month. The peak frequency is slightly smaller than 12 months, which indicates that the major events are occurring before ending a year compared to the previous year. According to MPI-ESM-LR (CMIP5) model data, future normal temperature on north-western region will be increased at a rate of $1.62^{\circ} \mathrm{C}$ during the period $2040-2100$.
\end{abstract}

\section{Keywords}

Trend Analysis, Mann-Kendall Test, Sen's Slope Estimator, Z-Test, CMIP5 Model and Periodicity 


\section{Introduction}

The Inter-Governmental Panel on Climate Change (IPCC) defines climate change as a change in the state of the climate that can be identified (e.g. using statistical tests) by changes in the mean and/or the variability of its properties and that persists for an extended period, typically decades or longer [1]. Weather changes in extreme and climate condition have important impacts that square measure the foremost serious challenges to society [2]. Temperature and precipitation variability is the very important side influencing on climate variability and extremes [3]. According to the IPCC (2007), due to continuing warming as a result of the climate changes, the world population can become rather more sufferer. Bangladesh, a south-Asian domain, is high ranked within the list of most climate-vulnerable countries on earth [4] [5]. High temperatures, heavy rainfall and seasonal variation square measure the distinctive characteristics that distinguish the climate of Bangladesh from that of other tropical regions [6]. Different climate changes occur in Bangladesh such as river bank erosion, floods, downing ground water level, increasing salinity, drought in rainy season which have been contributing to increase the vulnerability of many regions. However, many regions of this country remained outside the field of climate change related actions [7]. And also, the information on long term climatic trends is infrequent and insufficient in Bangladesh [8]. From the environmental condition point of view and meteorological consideration, four distinct seasons can be acknowledged in Bangladesh: 1) winter (December - February), 2) pre-monsoon (March - May), 3) monsoon (June - September) and 4) post-monsoon (October - November) [9] [10]. By using historical data of some selected meteorological stations, temperature has been modified [11] [12]. The rate of temperature increment will be higher than the present [13]. Throughout the past 100 years, a rise of temperature over Bangladesh is $0.5^{\circ} \mathrm{C}$ [14]. Another study shows mean annual temperature of Bangladesh has increased during the period of $1895-1980$ at $0.3^{\circ} \mathrm{C}$ over the past two decades [15] [16]. In general, associated degree of increasing trend found in both summer and winter temperatures [17].

Annual mean maximum temperature will increase to $0.4^{\circ} \mathrm{C}$ and $0.73^{\circ} \mathrm{C}$ by the year of 2050 and 2100 severally [18]. Rainfall is the main physical method that transports water from the atmosphere back to Earth's surface and links weather, climate and hydrological cycles [19] [20]. The rainfall dominated climate of Bangladesh receives the heaviest rainfall within the world [21]. There was no significant trend within the annual rainfalls of Bangladesh [22]. The study on the long-term monsoon rainfall pattern at 12 stations in Bangladesh found no overall trend in seasonal total rainfall but there detected some trends in monthly rainfalls [23]. The summer monsoon is the main rainy season in Bangladesh that accounts for approximately $72 \%$ of the annual rainfall throughout summer monsoon season [24]. But another study shows more than $75 \%$ rainfall occurs within the monsoon period while others show monsoon rainfall accounts for about $85 \%$ of the total rainfall [6] [25]. And the first two months of monsoon 
receive about $71 \%$ of its total monsoon rainfall throughout (2001-2004) over Bangladesh [26]. By using TRMM data, the minimum rainfall area was Rajshahi particularly close to Ishurdi per monsoon over South Asia [27]. The reduction of cold days is related to the rise of temperature and it's conjointly among a reduction of the areas of utmost cool temperatures and increase of the areas of utmost warmth [28]. Detection of trends in long time series of hydrological data is of paramount scientific and practical significance [29]. Climate analysis results are also dependent on the quality of the datasets, above all on its homogeneity [30]. Projected changes are massive that merely counting on ancient ways of extremes estimation would not seem to be prudent. Indeed, the climate change signal is already clearly distinguishable in several variables [31]. Climate models are one amongst the foremost wide used tools for developing projections of climate change within the future [32]. The new sets of climate model output become available for the IPCC Fifth Assessment Report (AR5) which are also known as the CMIP5 (5th Phase Coupled Model Inter-comparison Project) multi-model dataset [33]. Global Climate Models (GCMs) in CMIP5 are better in the sense that they represent more of the relevant climate processes in more detail than CMIP3 models. Moreover, they have a wider range of projections which will be very useful to capture a wide range of model uncertainties as mentioned [34]. The Earth's surface is divided up into a grid of cells and the fluid equations are discretized for each cell. Other processes are parameterized and included, such as convective motion [35]. This paper will go for the North-Western part of Bangladesh to investigate climate characteristics and comparison between Bangladesh Meteorological Department (BMD) data and 5th Phase Coupled Model Inter-comparison Project (CMIP5) model data for maximum temperature and rainfall during the period 1981 to 2008 and also the detection of trend of future mean temperature during the period 2040 to 2100 by using MPI-ESM-LR (CMIP5) model data. The remaining part of this paper is structured as the following: Section 2 gives data and methodology, Section 3 presents the results and discussion, while Section 4 gives the conclusion of the study.

\section{Data and Methodology}

\subsection{Study Area}

The north-western part of Bangladesh denotes the Rajshahi Division and Rangpur Division. Generally, it is the area lying west of Jamuna River and north of Padma River, and includes the Barind Tract. There are six meteorological stations are situated in this region which are Bogra, Rangpur, Dinajpur, Ishurdi, Rajshahi and Sydpur. Table 1 and Figure 1 show the locations of these stations.

\subsection{Data Sources and Processing}

Daily maximum temperature and normal daily rainfall data were collected from Bangladesh Meteorological Department (BMD) for the period 1981-2008. But 
Table 1. Geographical location of BMD stations inside the north central region.

\begin{tabular}{cccc}
\hline Station Name & Station ID & Latitude & Longitude \\
\hline Dinajpur & 10,120 & 25.65 & 88.67 \\
Rangpur & 10,208 & 25.73 & 89.27 \\
Rajshahi & 10,320 & 24.37 & 88.70 \\
Bogra & 10,408 & 24.87 & 89.35 \\
Ishurdi & 10,910 & 24.13 & 89.50 \\
Sydpur & 41,858 & 25.78 & 88.89 \\
\hline
\end{tabular}

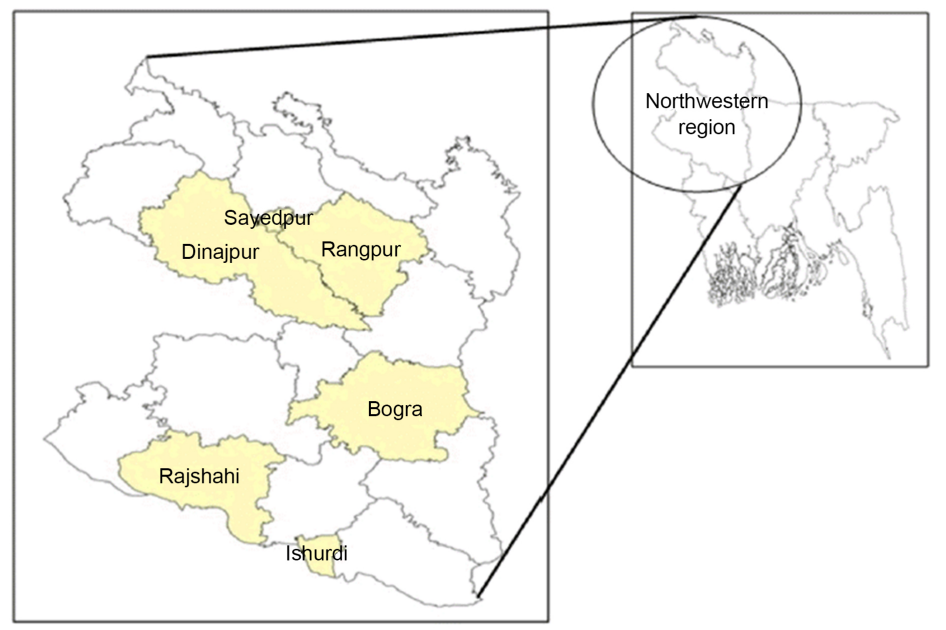

Figure 1. Location of BMD stations under the north-western region.

the data during the period 1981-1990 for the station of Sydpur was not available so that only for this station the value is calculated from 1991-2008. The missing data of temperature have been filled by inverse distance weighting method (IDW). Missing data of rainfall has been filled by data of the neighbor station.

On the other hand, to get and prepare MPI-ESM-LR (CMIP5) model data for calculation is complex and takes several processes. First of all, downloaded the Netcdf file of the data and then crack the NC file by using ArcMap software. Daily maximum temperature and normal daily rainfall data were collected for north-western region of Bangladesh for the period 1981-2008. But the rainfall data was available for the period 1981-2005. The MPI-ESM-LR (CMIP5) model data gives the same value for Rangpur, Dinajpur and Sydpur due to very near longitude and latitude and also same for the station Rajshahi and Ishurdi.

\subsection{Methodology}

Trend analysis is the prediction of future outcome by using historical result. Increasing or decreasing trend of all the independent weather parameters (e.g. annual and seasonal temperature, rainfalls, sunshine etc.) were statistically examined in two phases. First one is the using of non-parametric Mann-Kendall test and second one is the nonparametric Sens slope estimator. The increasing or decreasing trend was tested based on normalized test statistics $(Z)$ value. When 
$Z$ is positive, trend is said to be increasing and when $Z$ is negative, it is said to be decreasing. The trend's slope gives the annual rate and direction of change [36] [37] [38].

The Mann-Kendall trend test is a non-parametric way for identifying trends in data collected over time series. Mann-Kendall Statistic $(S)$ is given by,

$$
S=\sum \sum \operatorname{sign}\left(X_{i}-X_{j}\right)
$$

here, $i=2,3, \cdots, n ; j=1,2, \cdots, i-1$ and

$$
\operatorname{sign}\left(X_{i}-X_{j}\right)= \begin{cases}1, & \text { if } X_{i}-X_{j}>0 \\ 0, & \text { if } X_{i}-X_{j}=0 \\ -1, & \text { if } X_{i}-X_{j}<0\end{cases}
$$

For a sample size $>10$, a normal approximation to the Mann-Kendall test may be used. For this, variance of $\mathrm{S}$ is obtained as,

$$
V(s)=\frac{n(n-1)(2 n+1)-\sum t_{p}\left(t_{p}-1\right)\left(2 t_{p}+5\right)}{18}
$$

here, $p=1,2, \cdots, q$

where $t_{p}$ is the number of ties for the $p$ th value and $q$ is the number of tied values.

Then standardized statistical test is computed by:

$$
\operatorname{sign}\left(X_{i}-X_{j}\right)= \begin{cases}\frac{S-1}{\sqrt{V(s)}}, & \text { if } S>0 \\ 0, & \text { if } S=0 \\ \frac{S+1}{\sqrt{V(s)}}, & \text { if } S<0\end{cases}
$$

The magnitude of the trend is estimated by Sens slope method [39] which is proceeds by calculating the slope as a change in measurement per change in time,

$$
Q^{\prime}=\frac{x_{t^{\prime}}-x_{t}}{t^{\prime}-t}
$$

where, $Q^{\prime}$ is the slope between data points $x_{t^{\prime}}$ and $x_{t}, x_{t^{\prime}}$ is the data measurement at time $t^{\prime}$ and $x_{t}$ is the data measurement at time $t$.

Sens slope estimator is simply given by the median slope,

$$
\mathcal{B}= \begin{cases}\frac{Q_{N+1}^{\prime}}{2} & N \text { is odd } \\ \frac{1}{2}\left(Q_{\frac{N}{2}}^{\prime}+Q_{\frac{N+2}{2}}^{\prime}\right), & N \text { is even }\end{cases}
$$

where, $N$ is the number of calculated slopes. A positive value of B indicates an increasing trend and a negative value indicates a decreasing trend in the time series.

In this study to represent the confidence level ${ }^{* * *},{ }^{* *},{ }^{*}$ and + signs have been used to represent 100\%, 99\%, 95\% and $90 \%$ level of confidence respectively. 
Some researchers recommend the Shapiro-Wilk test as the best choice for testing the normality of data [40] and it has the best power for a given significance [41]. The ShapiroWilk test utilizes the null hypothesis principle to check whether a sample $x_{1} \cdots x_{n}$ came from a normally distributed population. The test statistic is,

$$
W=\frac{\left(\sum_{i=1}^{n} a_{i} x_{i}\right)^{2}}{\sum_{x=1}^{n}\left(x_{i}-\bar{x}\right)^{2}}
$$

where, $X_{i}$ is the $\mathrm{i}^{\text {th }}$ order statistic, i.e., the $\mathrm{i}^{\text {th }}$-smallest number in the sample mean, $a_{i}$ is the constant. The correlation coefficient determines the strength of linear relationship between two variables. It always takes a value between 1 and +1 , with 1 or 1 indicating a perfect correlation. A correlation coefficient close to or equal to zero indicates no relation-ship between the variables. A positive correlation coefficient indicates a positive (upward) relationship and a negative correlation coefficient indicates a negative (downward) relationship between the variables.

\section{Results and Discussion}

\subsection{Trend and Normality Test of Maximum Temperature and Rainfall}

In this chapter outcomes, daily maximum temperature and rainfall records of 28 years (1981-2008) have been analyzed based on temperature and rainfall of BMD data and MPI-ESM-LR (CMIP5) model data for the North-Western (Bogra, Rangpur, Dinajpur, Ishurdi, Rajshahi and Sydpur) region of Bangladesh. It is seen from Figure 2(a) that across the North-Western region in November, December, January and February average maximum temperature stays below $27^{\circ} \mathrm{C}$ according to BMD data and below $32^{\circ} \mathrm{C}$ according to MPI-ESM-LR (CMIP5) model data. April to October temperature cross $32^{\circ} \mathrm{C}$ and $42^{\circ} \mathrm{C}$ respectively is in accordance with BMD data and MPI-ESM-LR (CMIP5) model data. On the other hand, it is seen from Figure 2(b) that across the North-Western region in November, December, January and February normal rainfall is lowest in conformity to both BMD data and MPI-ESM-LR (CMIP5) model data. Major rainfalls have been observed in June, July, August and September about $349.64 \mathrm{~mm}$ and $137.66 \mathrm{~mm}$ respectively according to BMD data and MPI-ESM-LR (CMIP5) model data. Table 2 shows that highest average temperature has been detected in pre-monsoon season and it gradually decrease in winter where highest normal rainfall has been detected in monsoon season and it gradually decreased to winter and started increase from pre-monsoon according to both BMD data and MPI-ESM-LR (CMIP5) model data. It is seen that winter seasonal average maximum temperature was $25.43^{\circ} \mathrm{C}$ and $31.49^{\circ} \mathrm{C}$ respectively according to $\mathrm{BMD}$ data and MPI-ESM-LR (CMIP5) model data where winter seasonal normal rainfall was $10.57 \mathrm{~mm}$ and $3.45 \mathrm{~mm}$ respectively according to BMD data and MPI-ESM-LR (CMIP5) model data. Average $32.32^{\circ} \mathrm{C}$ and $41.50^{\circ} \mathrm{C}$ temperature has been calculated for North-Western region with $\mathrm{SD} 0.82^{\circ} \mathrm{C}$ and $2.36^{\circ} \mathrm{C}$ in monsoon 


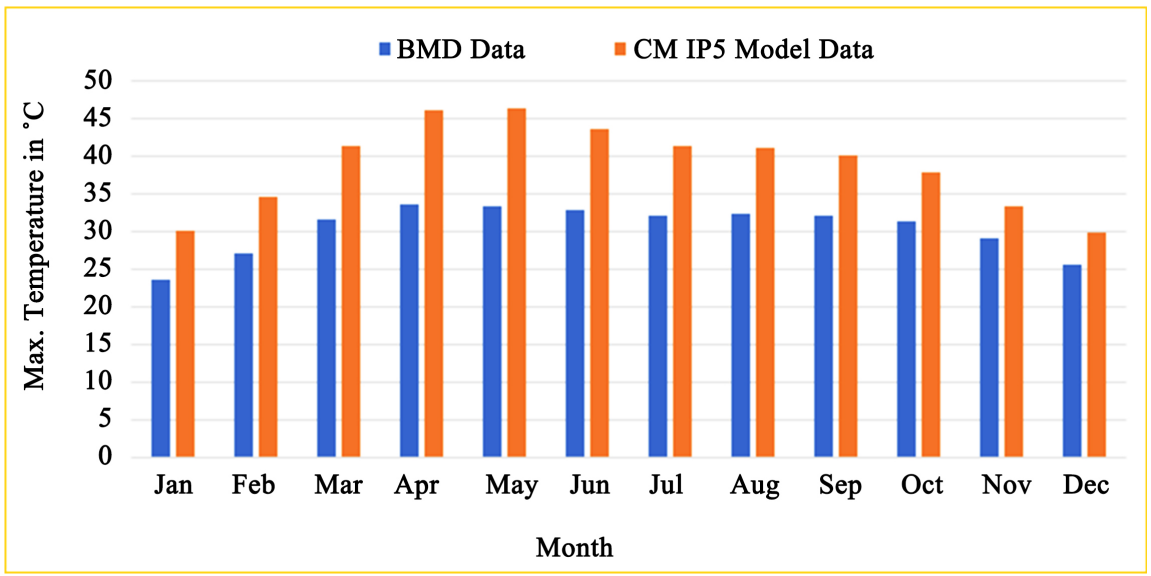

(a)

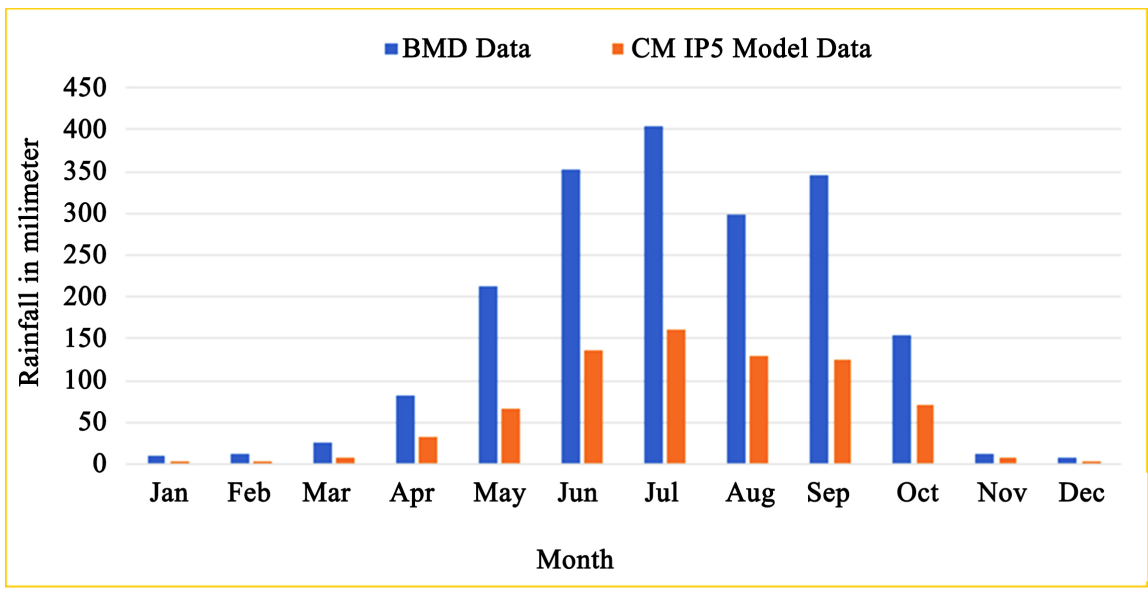

(b)

Figure 2. Bar diagram of (a) average monthly temperature and (b) rainfall in North-Western during the period 1981-2008 for BMD and MPI-ESM-LR (CMIP5) model data.

Table 2. Seasonal average maximum temperature and rainfall in North-Western during the period (1981-2008) for BMD and MPI-ESM-LR (CMIP5) model data.

\begin{tabular}{|c|c|c|c|c|c|c|c|c|}
\hline & & \multicolumn{3}{|c|}{ Maximum Temperature $\left({ }^{\circ} \mathrm{C}\right)$} & \multicolumn{4}{|c|}{ Rainfall (mm) } \\
\hline & & Mean & & SD & & Mean & & SD \\
\hline Season & BMD & MPI-ESM-LR & $\mathrm{BMD}$ & MPI-ESM-LR & BMD & MPI-ESM-LR & $\mathrm{BMD}$ & MPI-ESM-LR \\
\hline Winter & 25.43 & 31.49 & 1.85 & 2.99 & 10.57 & 3.45 & 15.87 & 6.73 \\
\hline Pre-monsoon & 32.82 & 44.66 & 1.74 & 3.18 & 107.03 & 35.93 & 119.85 & 49.18 \\
\hline Monsoon & 32.32 & 41.50 & 0.82 & 2.36 & 349.65 & 137.65 & 166.86 & 89.72 \\
\hline Post-monsoon & 30.27 & 35.63 & 1.29 & 2.73 & 82.72 & 38.73 & 123.30 & 47.52 \\
\hline
\end{tabular}

respectively in conformity with BMD data and MPI-ESM-LR (CMIP5) model data while post-monsoon average maximum temperature was $30.27^{\circ} \mathrm{C}$ and $35.63^{\circ} \mathrm{C}$ with SD $1.29^{\circ} \mathrm{C}$ and $2.73^{\circ} \mathrm{C}$ respectively according to $\mathrm{BMD}$ data and MPI-ESM-LR (CMIP5) model data. Highest $349.65 \mathrm{~mm}$ and $137.65 \mathrm{~mm}$ with SD $166.86 \mathrm{~mm}$ and $89.72 \mathrm{~mm}$ was observed in monsoon season while post-monsoon 
rainfall was $82.72 \mathrm{~mm}$ and $38.73 \mathrm{~mm}$ with SD $123.30 \mathrm{~mm}$ and 47.52 respectively according to BMD data and MPI-ESM-LR (CMIP5) model data. The temperature may be increasing due to rapid industrialization, greenhouses gases such as carbon dioxide, methane, nitrous oxides, chlorofluorocarbon (CFC).

It is seen from Table 3 that only $1.92 \%$ rainfall have occurred in winter in conformity with BMD data and only $1.60 \%$ rainfall have occurred in winter which in conformity with MPI-ESM-LR (CMIP5) model data. Highest $63.58 \%$ and $63.80 \%$ of total rainfall have occurred in monsoon respectively in accordance with BMD data and MPI-ESM-LR (CMIP5) model data.

Table 4 shows the seasonal trend of North-Western region. Trends of winter season have become lowered about $0.011^{\circ} \mathrm{C}$ for BMD data and rest of all are positive for both BMD data but for MPI-ESM-LR (CMIP5) model data every season have become upward. No passes the normality test for pre-monsoon and rest of three seasons passes the normality test for both BMD data and MPI-ESM-LR (CMIP5) model data. Besides that, only trend of post-monsoon is positive for both the BMD data and MPI-ESM-LR (CMIP5) model data about $1.378 \mathrm{~mm}$ and $1.464 \mathrm{~mm}$ respectively. No passes the normality test for winter and post-monsoon and other two seasons passes the normality test for BMD data but monsoon and post-monsoon passes the normality test for MPI-ESM-LR (CMIP5) model data.

Seasonal Mann-Kendall trend and Sens slope are shown in Table 5. The increase of monsoon maximum temperature is statistically significant for BMD data while winter is strongly significant for MPI-ESM-LR (CMIP5) model data.

Table 3. Percentage in rainfall of the different season for both BMD and MPI-ESM-LR (CMIP5) model data.

\begin{tabular}{ccc}
\hline Season & BMD (\%) & MPI-ESM-LR (\%) \\
\hline Winter & 1.92 & 1.60 \\
Pre-monsoon & 19.46 & 16.65 \\
Monsoon & 63.58 & 63.80 \\
Post-monsoon & 15.04 & 17.95 \\
\hline
\end{tabular}

Table 4. Trend $\left({ }^{\circ} \mathrm{C} /\right.$ year $)$ of seasonal average maximum temperature and rainfall in North-Western during the period (1981-2008) for BMD and MPI-ESM-LR (CMIP5) model data.

\begin{tabular}{cccccccccccccc}
\hline \multicolumn{1}{c}{ Maximum Temperature $\left({ }^{\circ} \mathrm{C}\right)$} & \multicolumn{7}{c}{ Rainfall $(\mathrm{mm})$} \\
\hline & Linear Slope & P-Value & P.N.T & Linear Slope & P-Value & \multicolumn{2}{c}{ P.N.T } \\
\hline Season & BMD & MPI & BMD & MPI & BMD & MPI & BMD & MPI & BMD & MPI & BMD & MPI \\
Winter & -0.011 & 0.049 & 0.352 & 0.248 & Yes & Yes & -0.386 & -0.413 & 0.0001 & 0.008 & No & No \\
Pre-monsoon & 0.015 & 0.057 & 0.0001 & 0.0001 & No & No & -0.349 & -0.284 & 0.625 & 0.005 & Yes & No \\
Monsoon & 0.024 & 0.037 & 0.856 & 0.207 & Yes & Yes & -0.345 & -1.629 & 0.996 & 0.219 & Yes & Yes \\
Post-monsoon & 0.008 & 0.059 & 0.167 & 0.762 & Yes & Yes & 1.378 & 1.464 & 0.0004 & 0.770 & No & Yes \\
\hline
\end{tabular}


Table 5. Mann-kendall trend test and Sens slope estimate of seasonal average maximum temperature and rainfall in North-Western during the period (1981-2008) for BMD and MPI-ESM-LR (CMIP5) model data.

\begin{tabular}{|c|c|c|c|c|c|c|c|c|c|c|c|c|}
\hline \multirow[b]{3}{*}{ Season } & \multicolumn{6}{|c|}{$\begin{array}{c}\text { Maximum Temperature } \\
\left({ }^{\circ} \mathrm{C}\right)\end{array}$} & \multicolumn{6}{|c|}{$\begin{array}{l}\text { Rainfall } \\
(\mathrm{mm})\end{array}$} \\
\hline & \multicolumn{2}{|c|}{ Z-test } & \multicolumn{2}{|c|}{ Significance } & \multicolumn{2}{|c|}{ Sens Slope } & \multicolumn{2}{|c|}{ Z-test } & \multicolumn{2}{|c|}{ Significance } & \multicolumn{2}{|c|}{ Sens Slope } \\
\hline & $\mathrm{BMD}$ & MPI & $\mathrm{BMD}$ & MPI & $\mathrm{BMD}$ & MPI & $\mathrm{BMD}$ & MPI & $\mathrm{BMD}$ & MPI & BMD & MPI \\
\hline Winter & -0.61 & 3.30 & & $* * *$ & -0.009 & 0.125 & -1.28 & -1.05 & & & -0.255 & -0.080 \\
\hline Pre-monsoon & -0.38 & 0.81 & & & -0.009 & 0.029 & 0.35 & -0.54 & & & 0.446 & -0.350 \\
\hline Monsoon & 2.75 & 0.85 & $* *$ & & 0.024 & 0.023 & 0.68 & -1.24 & & & 1.307 & -1.504 \\
\hline Post-monsoon & 1.24 & 1.52 & & & 0.011 & 0.067 & 0.96 & 2.41 & & * & 1.795 & 1.478 \\
\hline
\end{tabular}

Positively changed for monsoon and post-monsoon for BMD data while all seasons are positively changed for MPI-ESM-LR (CMIP5) model data. Besides that, during the taken period, only winter rainfall has decreased $1.28 \mathrm{~mm}$ per year for BMD data and for MPI-ESM-LR (CMIP5) model data only post-monsoon rainfall has increased $2.41 \mathrm{~mm}$ which is significant.

Significance of the trend is assessed using a $Z$ value, where negative and positive scores of $Z$ denote downward and upward trends respectively. Figure 3(a) shows the maximum increase in August for BMD data while February for MPI-ESM-LR (CMIP5) model data. On the other hand, Figure 3(b) shows rainfall mostly decreases in the month of December both for BMD and MPI-ESM-LR (CMIP5) model data.

Figure 4 shows that annual average temperature was highest in 1999 with $30.9^{\circ} \mathrm{C}$ and in 1981 it was lowest with $29.6^{\circ} \mathrm{C}$ according to BMD data and in accordance with MPI-ESM-LR (CMIP5) model data highest average maximum temperature was in 2007 with $41^{\circ} \mathrm{C}$ and in 1985 it was lowest with $37.1^{\circ} \mathrm{C}$ while highest rainfall was in 1999 with $191.9 \mathrm{~mm}$ and it was lowest in 1994 with 100.7 $\mathrm{mm}$ according to BMD data and in accordance with MPI-ESM-LR (CMIP5) model data highest normal rainfall was in 1989 with $100.6 \mathrm{~mm}$ and it was lowest in 2004 with $38.6 \mathrm{~mm}$. The linear trend line indicates annual average maximum temperature increase at a rate of $0.25^{\circ} \mathrm{C}$ per century and $5.3^{\circ} \mathrm{C}$ per century according to BMD data and MPI-ESM-LR (CMIP5) model data respectively. On the other hand, the linear trend line indicates for annual rainfall decrease at a rate of $8.8 \mathrm{~mm}$ per century and $40.13 \mathrm{~mm}$ per century according to BMD data and MPI-ESM-LR (CMIP5) model data. The main reasons for this unusual temperature rise are the unplanned urbanization, excessive population density, and therefore the increase of cars, and public transports. Also, the utilization of fridges and air conditioners employed by the dense town dwellers create an enormous quantity of HFCs (hydrofluorocarbons) contribution to the air, that destroys the protecting ozonosphere of the earth.

\subsection{Periodicities in Maximum Temperature and Rainfall}

Average of the temporal variation of the 336 months average maximum temperature 


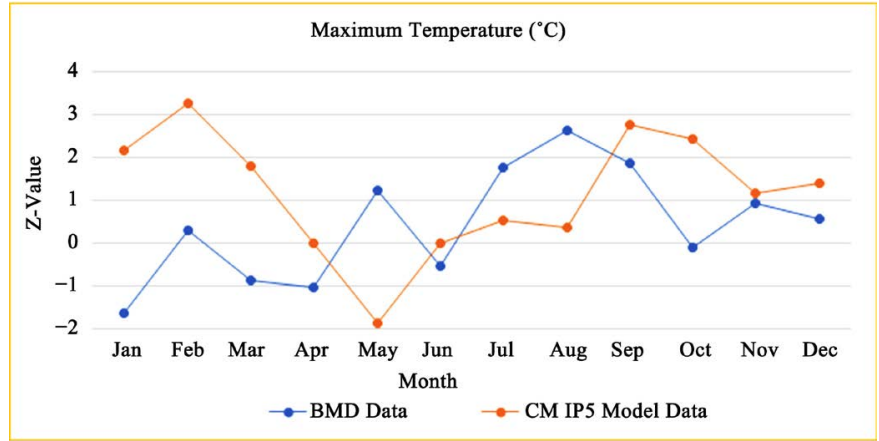

(a)

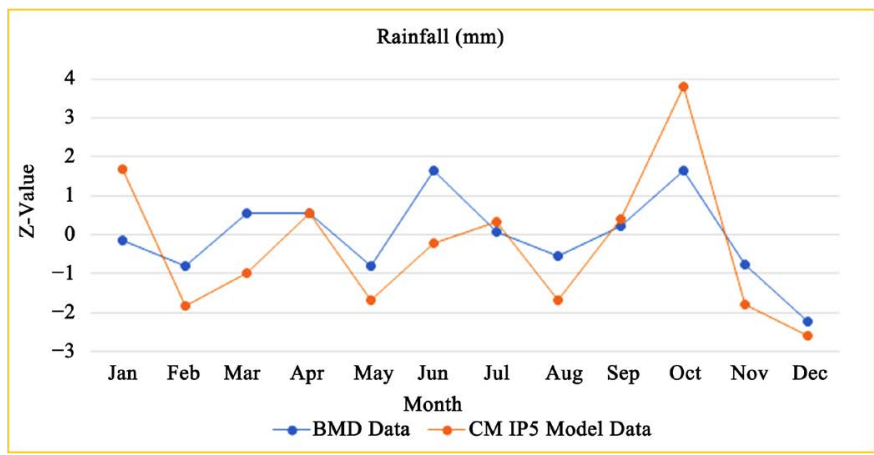

(b)

Figure 3. Comparison of Z-value of (a) Maximum Temperature and (b) Rainfall for BMD and MPI-ESM-LR (CMIP5) model data.

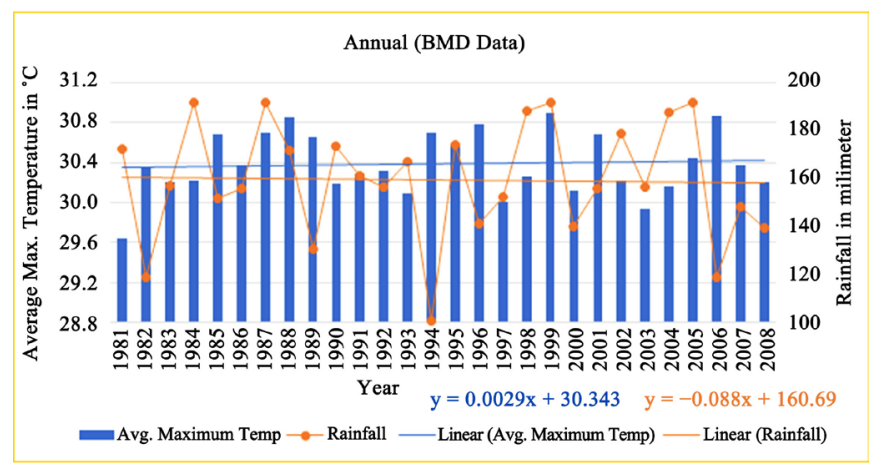

(a)

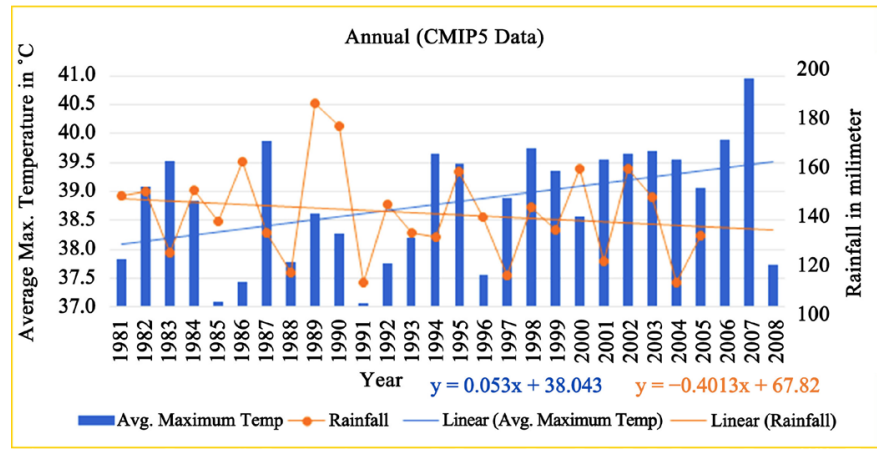

Figure 4. Time series and trend in annual average maximum temperature and rainfall in North-Western for (a) BMD and (b) MPI-ESM-LR (CMIP5) model data. 
record is $30.4^{\circ} \mathrm{C}$ and $38.8^{\circ} \mathrm{C}$ while rainfall record is $159.73 \mathrm{~mm}$ and $62.19 \mathrm{~mm}$ respectively according to BMD data and MPI-ESM-LR (CMIP5) model data. It seems from the time series that there is an extreme event above the mean value almost every year. The spectrum of monthly maximum temperature and rainfall variation both for BMD data and MPI-ESM-LR (CMIP5) model data is shown in Figure 5 and Figure 6 respectively which was normalized between 0 and 1.

For average maximum temperature, the periodogram shows three prominent peaks according to BMD data and two peaks in accordance to MPI-ESM-LR (CMIP5) model data while for rainfall two prominent peaks according to BMD data and one peak in accordance to MPI-ESM-LR (CMIP5) model data. It may be seen from the periodogram that, as a rough approximation the first two periodicity can be taken as significant and the others may be neglected for average maximum temperature while only first peak can be identified as significant for both data and the others may be neglected for rainfall. The period (in Months) corresponding to the first peak of the value of 0.084 is compound by $1 / 0.084$ results in periodicity of 12 months and the peak at 0.168 results in periodicity of 6

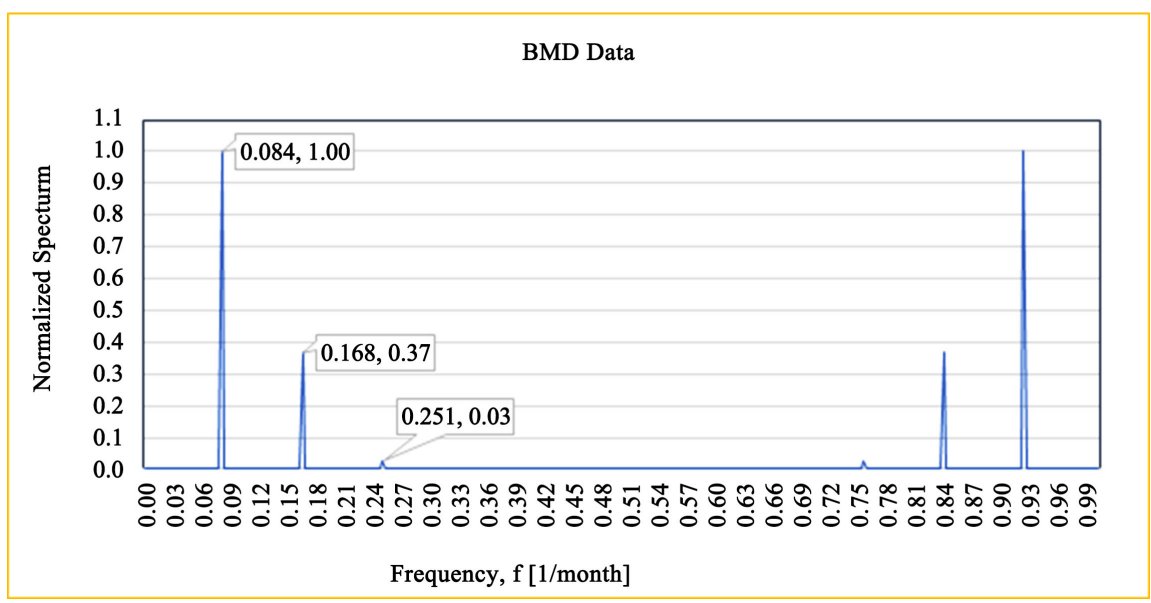

(a)

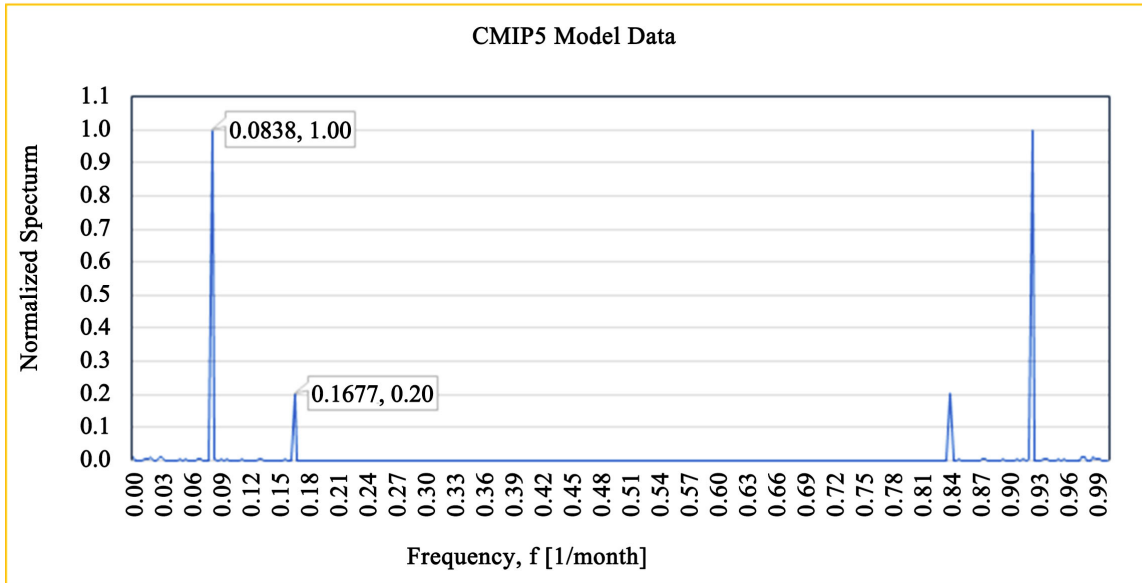

(b)

Figure 5. Monthly average maximum temperature in North-Western region for both BMD and MPI-ESM-LR (CMIP5) model data with its periodogram. 


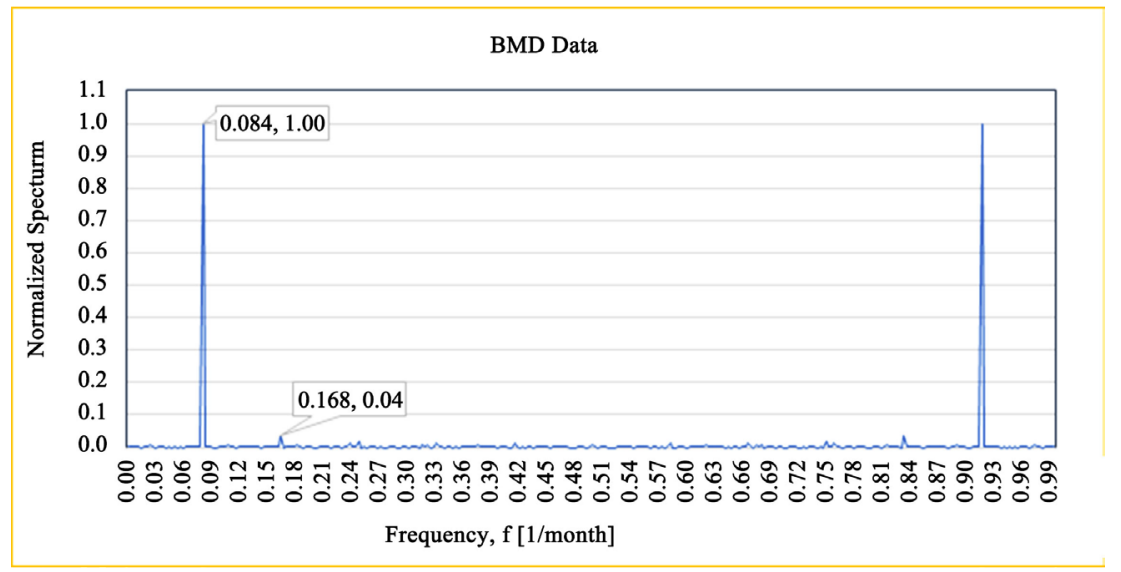

(a)

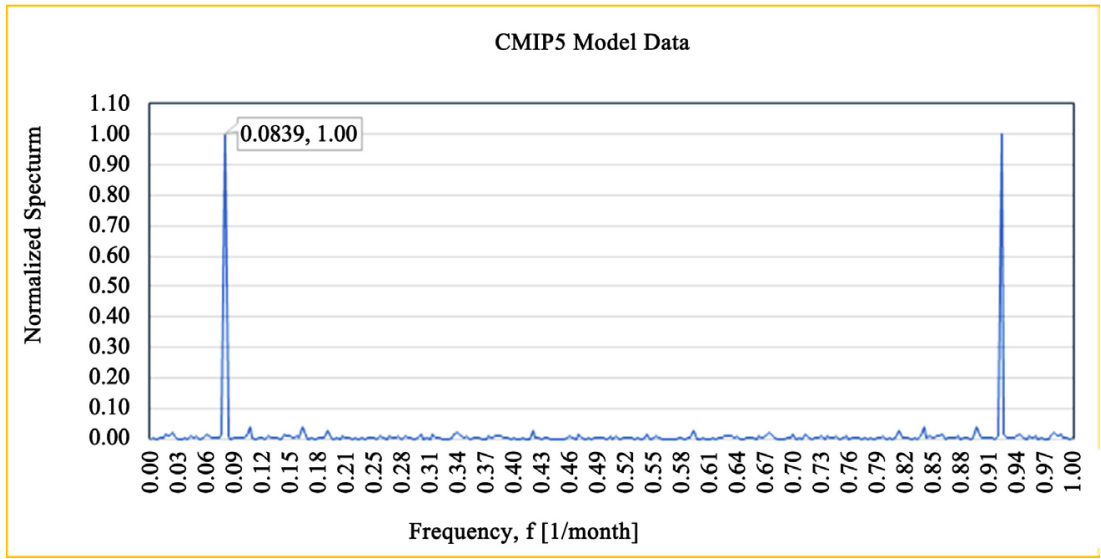

(b)

Figure 6. Monthly normal rainfall in North-Western for both BMD and MPI-ESM-LR (CMIP5) model data with its periodogram.

months both for average maximum temperature and rainfall according to BMD data but there is no such peak in MPI-ESM-LR (CMIP5) model data for six months periodicity for rainfall. According to BMD data the third peak at 0.251 results in a periodicity of four months but there is no such peak in MPI-ESM-LR (CMIP5) model data. However, the peak frequency is slightly smaller than one year which indicates that the major events are occurring before ending a year compared to the previous year. The reason for shifting the higher temperature and rainfall events may be climate change; though it is not logical to conclude that without more analysis.

Monthly average maximum temperature and rainfall variation was filtered through a band pass filter ( 0.080 to 0.086 per months) compared with the original monthly variation and displayed in Figure 7 and Figure 8 for both BMD data and MPI-ESM-LR (CMIP5) model data. The figure shows that the filtered signal follows reasonably well with the passage of major events. Hence, the FFT analysis captured successfully the major maximum temperature events but failed to indicate extreme events. The filtered signal can be used for prediction of major events such as higher maximum temperature. 
Figure 9 shows the maximum temperature and rainfall anomalies of BMD and MPI-ESM-LR (CMIP5) model data. The maximum temperature increased at a rate of $1.5^{\circ} \mathrm{C}$ and $3.5^{\circ} \mathrm{C}$ above average according to BMD data and CMPI5 model data in 1988. On the other hand, most rainfall increased at a rate of above $40 \mathrm{~mm}$ in 1994 according to BMD data but $20 \mathrm{~mm}$ increased in 1991 according to MPI-ESM-LR (CMIP5) model data.

The climatology of maximum temperature and rainfall based of BMD and MPI-ESM-LR (CMIP5) model datasets is presented in Figure 10 and Figure 11. The climatology shows that generally Ishurdi and Rajshahi parts temperature is most according to BMD data but Rangpur temperature is most in accordance with MPI-ESM-LR (CMIP5) model data. On the other hand, Rangpur receive the highest rainfall according to BMD data while Rangpur, Dinajpur and Sydpur parts record the least according to MPI-ESM-LR (CMIP5) model data.

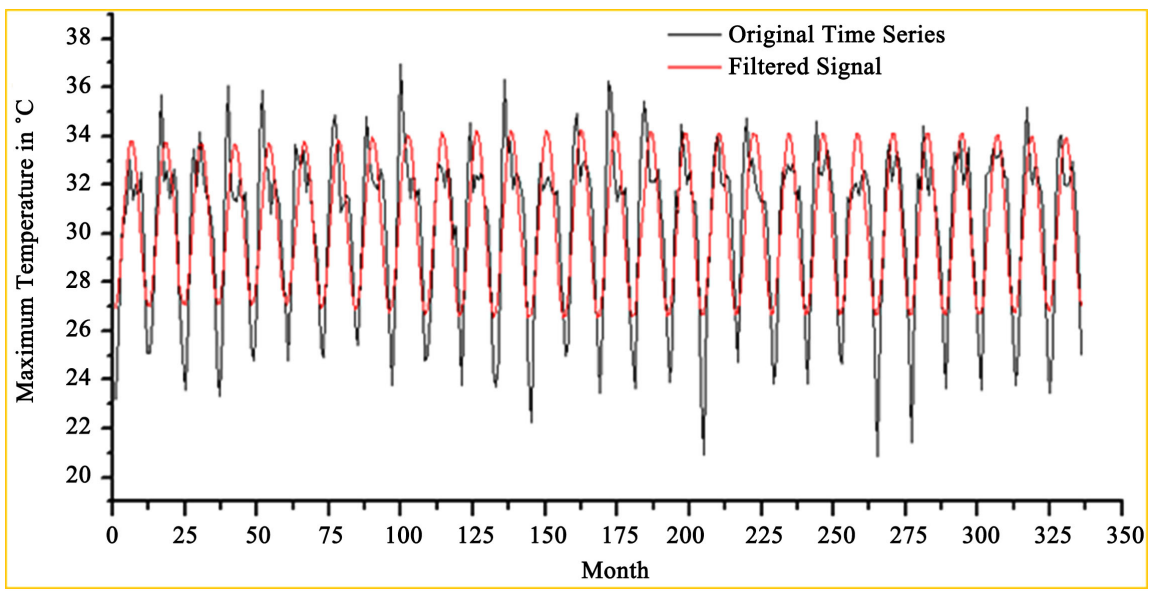

(a)

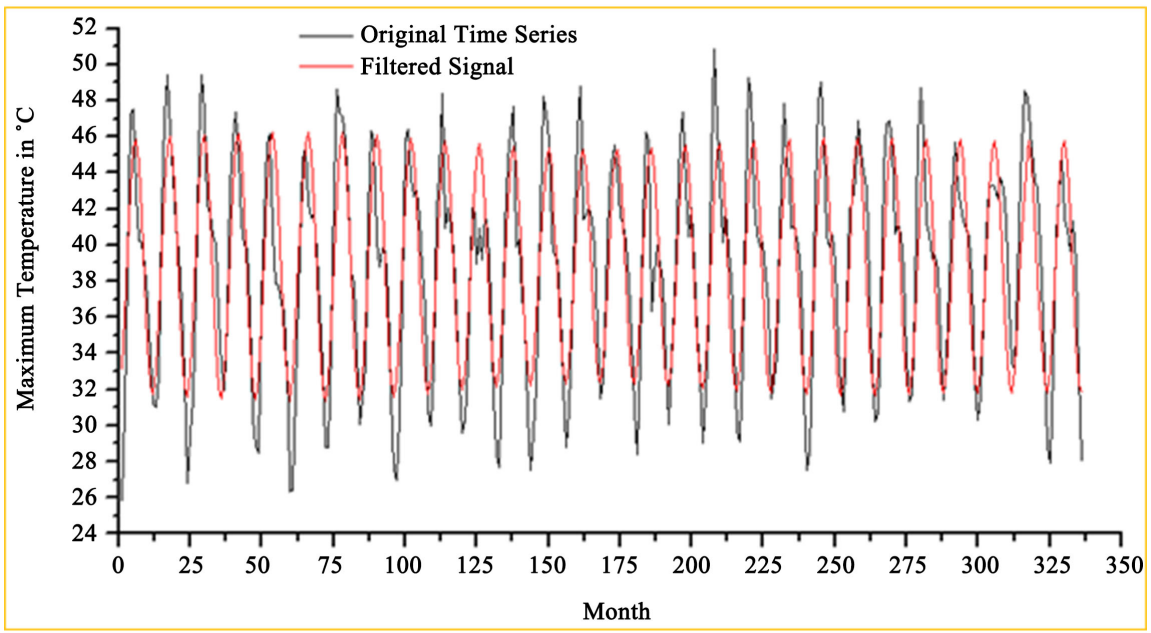

(b)

Figure 7. Comparison between original monthly average maximum temperature variation and filtered (with a band pass filter 0.080 to 0.086 per month) variation for both BMD and MPI-ESM-LR (CMIP5) model data. 


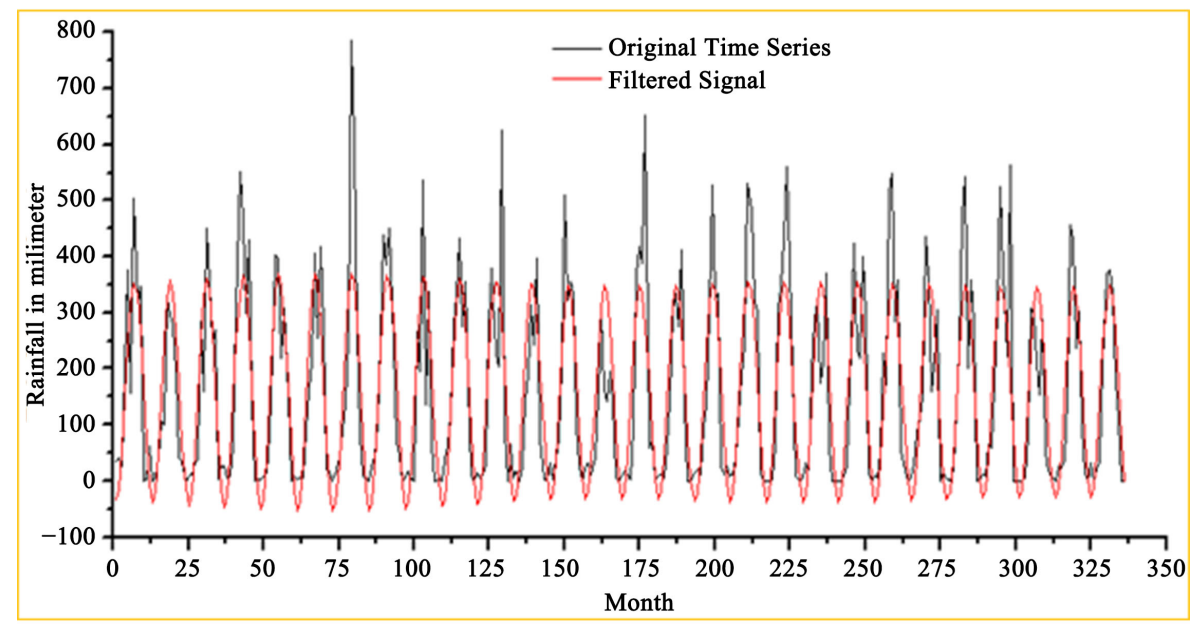

(a)

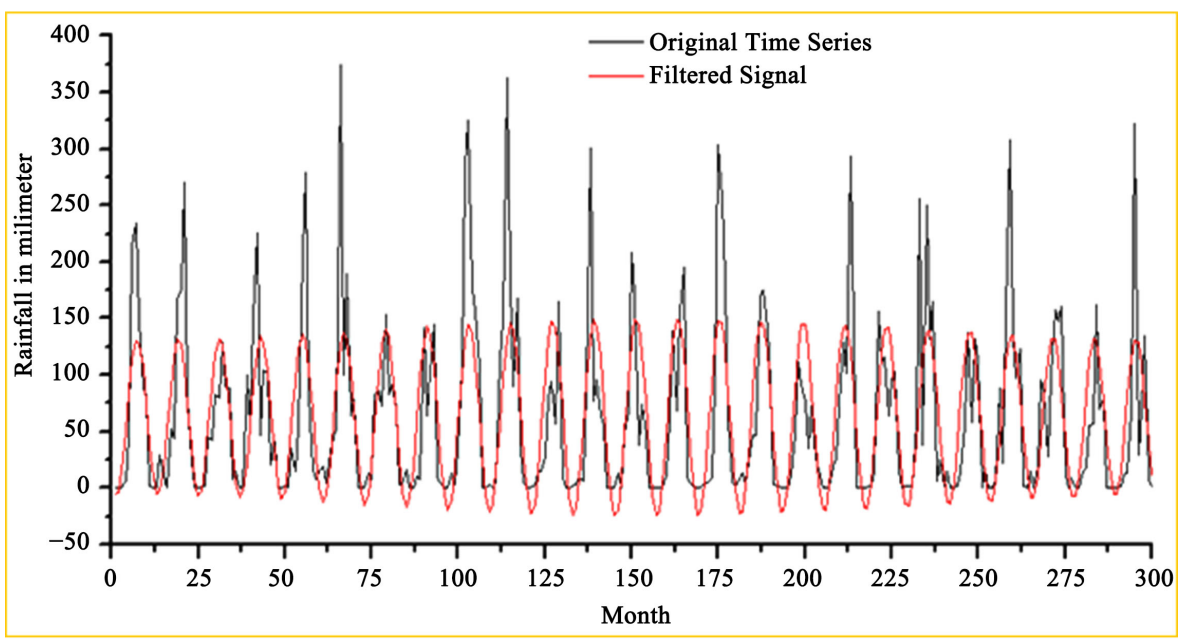

(b)

Figure 8. Comparison between original monthly normal rainfall variation and filtered (with a band pass filter 0.080 to 0.086 per month) variation for both BMD and MPI-ESM-LR (CMIP5) model data.

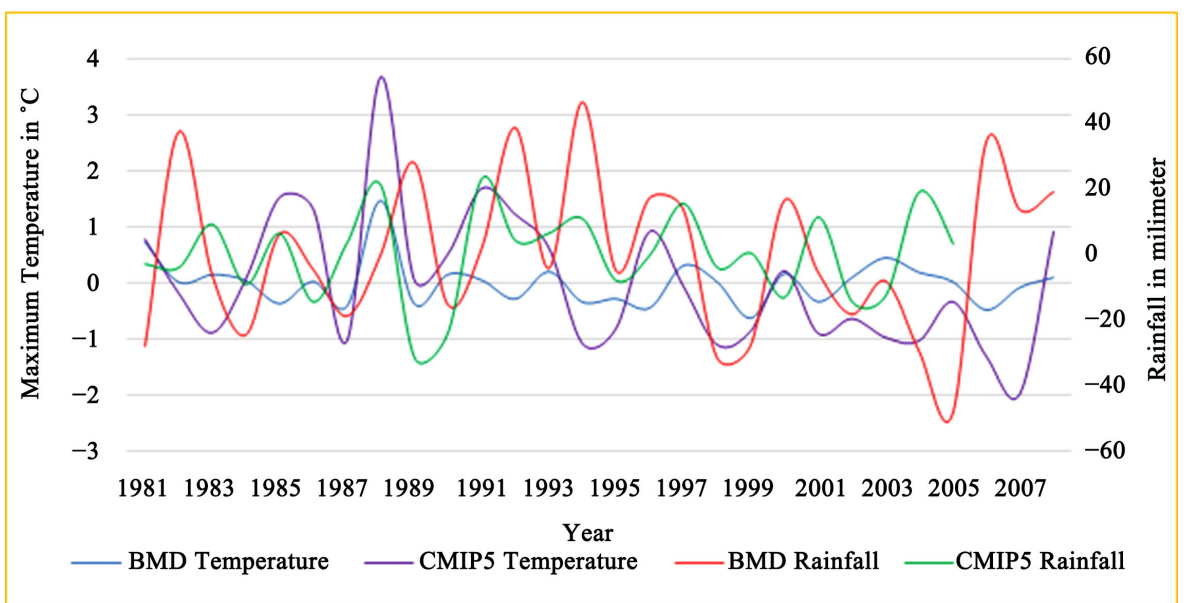

Figure 9. Maximum temperature and rainfall anomalies from (1980-2008) according to BMD and MPI-ESM-LR (CMIP5) model data. 

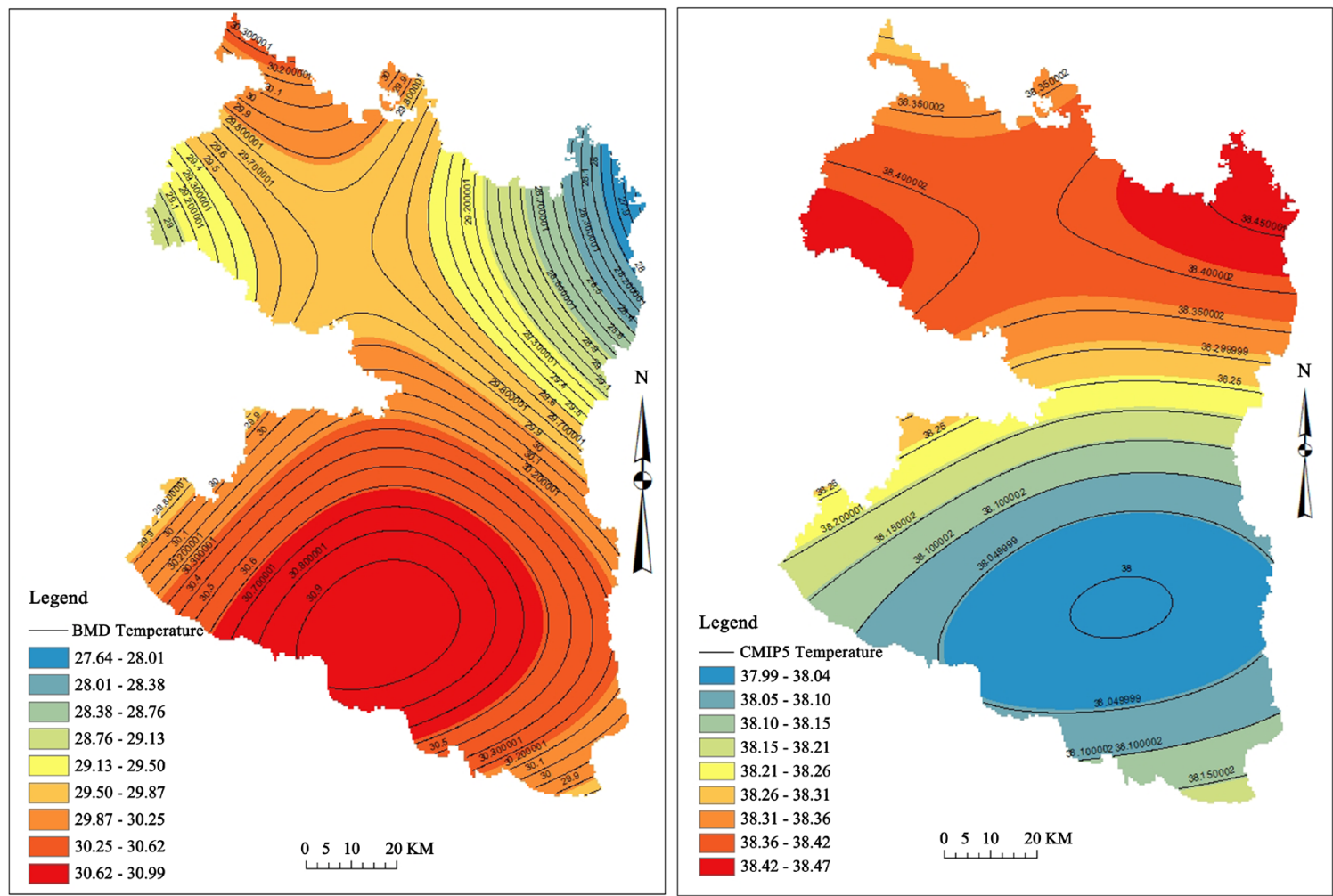

Figure 10. Geographical distribution of climatology for the maximum temperature in all season according to BMD and MPI-ESM-LR (CMIP5) model data.
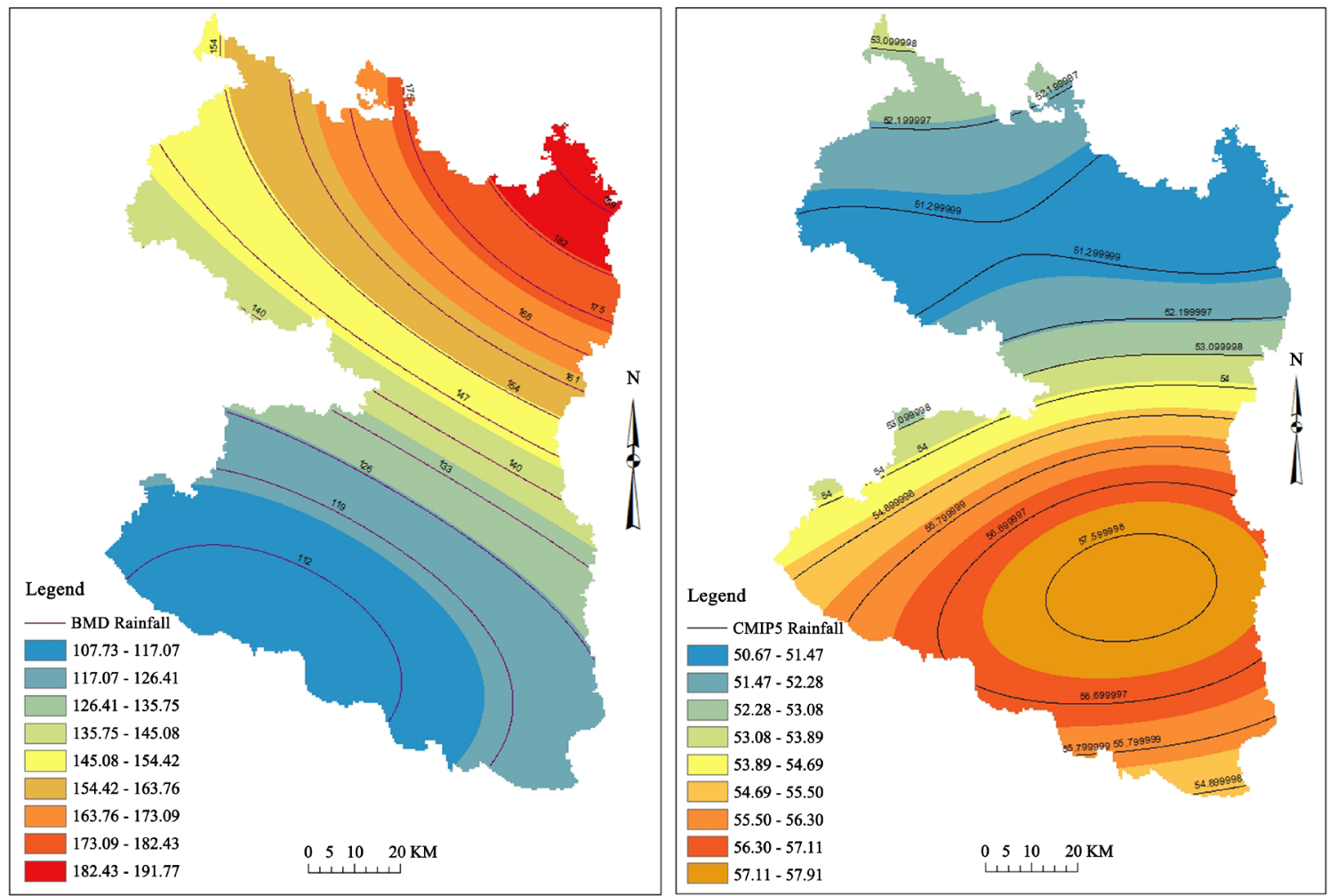

Figure 11. Geographical distribution of climatology for the rainfall in all season according to BMD and MPI-ESM-LR (CMIP5) model data. 


\subsection{Correlation between Maximum Temperature and Rainfall}

Table 6 shows the correlation coefficient and P-value of Pearsons r, Spearmans $\rho$ and Kendalls $\tau$ correlation methods for BMD data and MPI-ESM-LR (CMIP5) model data. It is seen from the table that each method shows negative correlation with rainfall and $P$-value shows the correlation is very significant with $100 \%$ confidence level.

Table 6. Correlation between avg. max. temperature and rainfall in North-Western for BMD and MPI-ESM-LR (CMIP5) model data.

\begin{tabular}{cccc}
\hline & & \multicolumn{2}{c}{ Correlation bet. max. temp. and rainfall } \\
\hline Pearson & $r$ & -0.064 & MPI-ESM-LR \\
& $P$-value & 0.761 & -0.055 \\
Spearman & $\rho$ & -0.093 & 0.796 \\
& $P$-value & 0.659 & -0.117 \\
& $\tau$ & -0.042 & 0.577 \\
Kendall & $\tau$ & 0.767 & -0.210 \\
& $P$-value & & 0.123 \\
\hline
\end{tabular}

\subsection{Analysis of Future Average Temperature according to MPI-ESM-LR (CMIP5) Model Data}

Changes of the mean annual temperature from 2040 till 2100 are shown in Figure 12. The average temperature using the MPI-ESM-LR (CMIP5) model is $28.27^{\circ} \mathrm{C}$ and the linear trend line indicates annual average temperature increase at a rate of $0.026^{\circ} \mathrm{C}$ during the year 2040 to 2100 . Slow increase of temperature up to year 2050 is observed whereas accelerated warming trend is observed. Significant increase of temperature is observed for the year 2050-2070 and during this time average temperature is $28.71^{\circ} \mathrm{C}$ where during the year $2070-2100$ average temperature is $28.59^{\circ} \mathrm{C}$. The maximum temperature is $30.86^{\circ} \mathrm{C}$ in the year of 2079. If this happen continuously then the temperature of North-Western will be increase at about $2.6^{\circ} \mathrm{C}$ for the next 100 years. This will seriously affect our daily life which will cause storms and floods, salinity of ground water, effects on agriculture and fisheries, health hazards to the people of the north-western region of Bangladesh as well as the whole country.

\section{Conclusion}

An examination on air temperature and precipitation behavior is important for short-term planning and the prediction of future climate conditions. Trends in precipitation and temperature at annual, seasonal and monthly time scales for the periods of 1981-2008 have been analyzed using BMD data and MPI-ESM-LR (CMIP5) model data. Also, the results herein form a good basis of future studies 


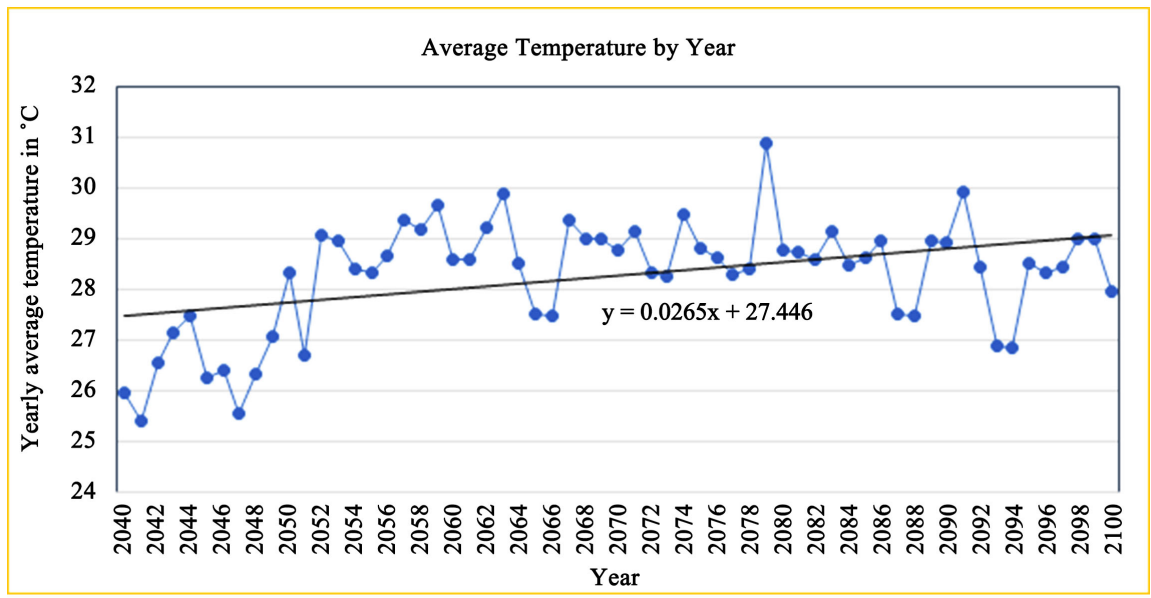

Figure 12. Time series and trend of yearly average temperature in North-Western during the period (2040-2100) for MPI-ESM-LR (CMIP5) model data.

on temperature variability. Considering all seasons (winter, pre-monsoon, monsoon and post-monsoon), maximum temperature has increased significantly in all seasons except winter which is insignificant over the whole study area for BMD data but for MPI-ESM-LR (CMIP5) model data maximum temperature is on increase in the region. On average, temperature over the entire region increased by $0.29^{\circ} \mathrm{C}$ and $5.3^{\circ} \mathrm{C}$ per century respectively for BMD data and MPI-ESM-LR (CMIP5) model data. It has clearly found that maximum temperature has been increased dramatically during the period of 1981-2008. In future, the normal temperature will be beyond $31^{\circ} \mathrm{C}$. The highest future normal temperature has occurred in Bogra at $8^{\circ} \mathrm{C}$ per century. For north-western region, the highest $63.58 \%$ and $63.80 \%$ of total rainfall have occurred in monsoon respectively in accordance with BMD data and MPI-ESM-LR (CMIP5) model data. In Dinajpur, the highest percent of rainfall occurred in monsoon for both BMD data and MPI-ESM-LR (CMIP5) model data. Winter rainfall has decreased $1.28 \mathrm{~mm}$ per year for BMD data and for MPI-ESM-LR (CMIP5) model data only post-monsoon rainfall has increased $2.41 \mathrm{~mm}$ which is significant. Only $1.92 \%$ rainfall has occurred in winter in conformity with BMD data and only $1.60 \%$ rainfall has occurred in winter in conformity with MPI-ESM-LR (CMIP5) model data. The lowest rainfall occurred in Sydpur with $8.30 \mathrm{~mm}$ in winter for BMD data and only $2.17 \mathrm{~mm}$ rainfall occurred in Rajshahi and Ishurdi for MPI-ESM-LR (CMIP5) model data. Overall, the rainfall is decreasing in north-western region. MPI-ESM-LR (CMIP5) temperature projections are larger than BMD climate projection but MPI-ESM-LR (CMIP5) precipitation projections are smaller than BMD climate projections. Though there is a difference between the values of BMD and MPI-ESM-LR (CMIP5), the decisions are almost the same for a small region like north-western region of Bangladesh. That's why, considering new MPI-ESM-LR (CMIP5) projections will be more helpful for decision makers as they have comparatively better representation of earth's physical processes. 


\section{Acknowledgements}

The authors express their appreciation to Mawlana Bhashani Science and Technology (MBSTU) research Cell for providing financial support that foster research. Special thanks go to Bangladesh Meteorological Department (BMD), World Climate Research Programme (WCRP) and Fifth Phase of Coupled Model Intercomparison Project (CMIP5) for providing data used in the study.

\section{References}

[1] Solomon, S., Qin, D., Manning, M., Chen, Z., Marquis, M., Averyt, K.B., Tignor, M. and Miller, H.L. (2007) Climate Change 2007: The Physical Science Basis: Working Group I Contribution to the Fourth Assessment Report of the IPCC. Cambridge University Press, Cambridge, New York.

[2] Karl, T.R., Meehl, G.A., Miller, C.D., Hassol, S.J., Waple, A.M. and Murray, W.L. (2008) Weather and Climate Extremes in a Changing Climate. A Report by the U.S. Climate Change Science Program and the Subcommittee on Global Change Research, Department of Commerce, NOAAs National Climatic Data Center, Washington DC, $164 \mathrm{p}$.

[3] Fahad, M., Islam, A., Islam, G. and Bala, S.K. (2015) The Projection of Temperature and Precipitation over Bangladesh under RCP Scenarios using CMIP5 Multi-Model Ensemble. Proceedings of the International Conference on Recent Innovation in Civil Engineering for Sustainable Development, Gazipur, 11-13 December 2015, WRE-037.

[4] Harmeling, S. (2008) Global Climate Risk Index 2009: Weather-Related Loss Events and Their Impacts on Countries in 2007 and in a Long-Term Comparison. Germanwatch e.V., Berlin, 5-8.

[5] Rajib, M.A., Rahman, M.M., Rakib, Z.B., Khondoker, M.T.H., Iskander, S.M., Hassan, M.M. and Mortuza, M.R. (2012) Application of RCM-Based Climate Change Indices in Assessing Future Climate: Part I Temperature Extremes. In: World Environmental and Water Resources Congress 2012: Crossing Boundaries, American Society of Civil Engineers, Reston, 1-7.

[6] Hossain, M.S., Roy, K. and Datta, D.K. (2014) Spatial and Temporal Variability of Rainfall over the South-West Coast of Bangladesh. Climate, 2, 28-46. https://doi.org/10.3390/cli2020028

[7] Titumir, R.A.M. and Basak, J.K. (2012) Effects of Climate Change on Crop Production and Climate Adaptive Techniques for Agriculture in Bangladesh. Social Science Review, 29, 215-232.

[8] Mondal, A.S.M., Islam, S. and Madhu, M.K. (2012) Spatial and Temporal Distribution of Temperature, Rainfall, Sunshine and Humidity in Context of Crop Agriculture, Comprehensive Disaster Management Programme (CDMP II). Ministry of Disaster Management and Relief, Dhaka, 1 p.

[9] Islam, M.N. and Uyeda, H. (2007) Use of TRMM in Determining the Climatic Characteristics of Rainfall over Bangladesh. Remote Sensing of Environment, 108, 264-276. https://doi.org/10.1016/j.rse.2006.11.011

[10] Ahasan, M.N., Chowdhary, M.A.M. and Quadir, D.A. (2010) Variability and Trends of Summer Monsoon Rainfall over Bangladesh. Journal of Hydrology and Meteorology, 7, 1-17.

[11] Chowdhury, M.H.K. and Debsharma, S.K. (1992) Climate Change in Bangladesh: A 
Statistical Review. Report on IOC-UNEP Workshop on Impacts of Sea Level Rise due to Global Warming.

[12] Mia, N.M. (2003) Variations of Temperature of Bangladesh. Proceedings of SAARC Seminars on Climate Variability in the South Asian Region and Its Impacts, Dhaka, 10-12 December 2002, 94.

[13] Rouf, M.A., Uddin, M.K., Debsarma, S.K. and Rahman, M.M. (2011) Climate of Bangladesh: An Analysis of North-Western and South-Western Part using High Resolution Atmosphere-Ocean General Circulation Model (AOGCM). A Scientific Journal of Krishi Foundation, 9, 143-154.

[14] Ahmad, Q.K., Warrick, R.A., Ericksen, N.J. and Mirza, M.M.Q. (1996) The Implications for Climate Change for Bangladesh: A Synthesis. In: Warrick, R.A. and Ahmad, Q.K., Eds., The Implications of Climate and Sea-Level Change for Bangladesh, Kluwer Academic Publishers, Dordrecht, 1-34.

[15] Parthasarathy, B., Sontake, N.A., Monot, A.A. and Kothawale, D.R. (1987) Drought-Flood in the Summer Monsoon Season over Different Meteorological Subdivisions of India for the Period 1871-1984. Journal of Climatology, 7, 57-70. https://doi.org/10.1002/joc.3370070106

[16] Mehrotra, D. and Mehrotra, R. (1995) Climate Change and Hydrology with Emphasis on the Indian Subcontinent. Hydrologic Sciences Journal, 40, 231-242.

[17] Islam, T. and Neelim, A. (2010) Climate Change in Bangladesh: A Closer Look into Temperature and Rainfall Data. The University Press Limited, Dhaka.

[18] Karmakar, S. and Shrestha, M.L. (2000) Recent Climate Change in Bangladesh. SMRC No. 4, SMRC, Dhaka.

[19] Kuchment, L.S. (2004) The Hydrological Cycle and Human Impact on It. In: Hoekstra, A.Y. and Savenije, H.H.G., Eds., Water Resources Management Encyclopaedia of Life Support Systems (EOLSS), Developed under the Auspices of the UNESCO, Eolss Publishers, Oxford.

[20] Rosenfeld, D., Lohmann, U., Raga, G.B., ODowd, C.D., Kulmala, M., Fuzzi, S. and Andreae, M.O. (2008) Flood or Drought: How Do Aerosols Affect Precipitation? Science, 321, 1309-1313. https://doi.org/10.1126/science.1160606

[21] Mirza, M.Q., Warrick, R.A., Ericksen, N.J. and Kenny, G.J. (2008) Trends and Persistence in Precipitation in the Ganges, Brahmaputra and Meghna River Basins. Hydrological Sciences Journal, 43, 845-858.

[22] Ahmed, S.M.U., Hoque, M.M. and Hussain, S. (1992) Floods in Bangladesh: A Hydrological Analysis. Final Report No. R01/92, IWFM, BUET.

[23] Rahman, M.R., Salehin, M. and Matsumoto, J. (1997) Trend of Monsoon Rainfall Pattern in Bangladesh. Journal of Water Resources, 14, 121-138.

[24] Ahasan, M.N., Chowdhury, M.A. and Quadir, D.A. (2008) Few Aspects of the Flood Disaster Caused by Heavy Rainfall over Bangladesh. Proceedings of SAARC Seminar on Application of Weather and Climate Forecasts in the Socio-Economic Development and Disaster Mitigation, Dhaka, 5-7 August 2007, 79-94.

[25] Roy, M. (2013) Time Series, Factors and Impacts Analysis of Rainfall in North-Eastern Part in Bangladesh. International Journal of Scientific and Research Publications, 3, 1-7.

[26] Bhuiyan, M.T.H., Bhuyan, M.D.I., Chowdhury, M. N., Wahid, C. and Faruque, S.B. (2014) Characteristics of Diurnal Variation of Summer Monsoon Rainfall over Bangladesh and Its Adjacent Areas. Journal of Emerging Trends in Engineering and Applied Sciences, 5, 217-221. 
[27] Bhuiyan, M.D.I., Islam, J., Wahid, C. and Faruque, S.B. (2013) Characteristics of Summer Monsoon Rainfall over South Asia using TRMM Data. Journal of Science and Technology, Mawlana Bhashani Science and Technology University, 3, 471-479.

[28] Jones, P.D., New, M., Parker, D.E., Martin, S. and Rigor, I.G. (1999) Surface Air Temperature and Its Variation over the Last 150 Years. Reviews of Geophysics, 37, 173-199. https://doi.org/10.1029/1999RG900002

[29] Kundzewicz, Z.W. and Robson, A. (2000) Detecting Trend and Other Changes in Hydrological Data World Climate Programme Data and Monitoring. WMO/TD-No. 1013, Geneva.

[30] Venema, V., Mestre, O., Aguilar, E., Auer, I., Guijarro, J.A., Domonkos, P., Vertacnik, G., Szentimrey, T., Stepanek, P., Zahradnicek, P., Viarre, J., Mller-Westermeier, G., Lakatos, M., Williams, C.N., Menne, M., Lindau, R., Rasol, D., Rustemeier, E., Kolokythas, K., Marinova, T. andresen, L., Acquaotta, F., Fratianni, S., Cheval, S., Klancar, M., Brunetti, M., Gruber, C., Duran, M.P., Likso, T., Esteban, P. and Brandsma, T. (2012) Benchmarking Monthly Homogenization Algorithms. Climate of the Past, 8, 89-115. https://doi.org/10.5194/cp-8-89-2012

[31] Hegerl, G.C., Zwiers, F., Stott, P. and Kharin, S. (2004) Detectability of Anthropogenic Changes in Annual Temperature and Precipitation Extremes. Journal of Climate, 17, 3683-3700.

[32] Hasan, M.A., Islam, G.M.S., Islam, T., Bala, S.K., Paul, S., Billah, M., Rahman, M.M. and Fahad, M.G.R. (2015) A Comparative Analysis of cmip3 and cmip5 Climate Projections over Bangladesh. 5th International Conference on Water and Flood Management, Dhaka, 6-8 March 2015, 573-580.

[33] Stocker, T.F., Qin, D., Plattner, G.K., Tignor, M., Allen, S.K., Boschung, J., Nauels, A., Xia, Y., Bex, V. and Midgley, P.M. (2013) Climate Change 2013. The Physical Science Basis. Working Group, I Contribution to the Fifth Assessment Report of the Intergovernmental Panel on Climate Change.

[34] Knutti, R. and Sedlek, J. (2013) Robustness and Uncertainties in the New CMIP5 Climate Model Projections. Nature Climate Change, 3, 369-373. https://doi.org/10.1038/nclimate1716

[35] White, B. (2007) Physics in the Current Climate. Institute of Physics, 42, 327-330.

[36] Kendall, M.G. (1995) Rank Correlation Methods. Charles Griffin, London.

[37] Helsel, D.R. and Hirsch, R.M. (2002) Statistical Methods in Water Resources. Chapter A3, Book 4, Hydrologic Analysis and Interpretation, Techniques of Water-Resources Investigations of the United States Geological Survey.

[38] Salmi, T., Maatta, A., Anttila, P., Ruoho-Airola, T. and Amnell, T. (2002) Detecting Trends of Annual Values of Atmospheric Pollutants by the Mann-Kendall Test and Sens Slope Estimates-The Excel Template Application Makesens. Finnish Meteorological Institute Publications on Air Quality No. 31, Helsinki.

[39] Sen, P.K. (1968) Estimates of the Regression Coefficient Based on Kendalls Tau. Journal of the American Statistical Association, 63, 1379-1389.

https://doi.org/10.1080/01621459.1968.10480934

[40] Thode, H.J. (2002) Testing for Normality. Marcel Dekker, New York. https://doi.org/10.1201/9780203910894

[41] Razali, N.M. and Wah, Y.B. (2011) Power Comparisons of ShapiroWilk, KolmogorovSmirnov, Lilliefors and Anderson-Darling Tests. Journal of Statistical Modelling and Analytics, 2, 2133. 